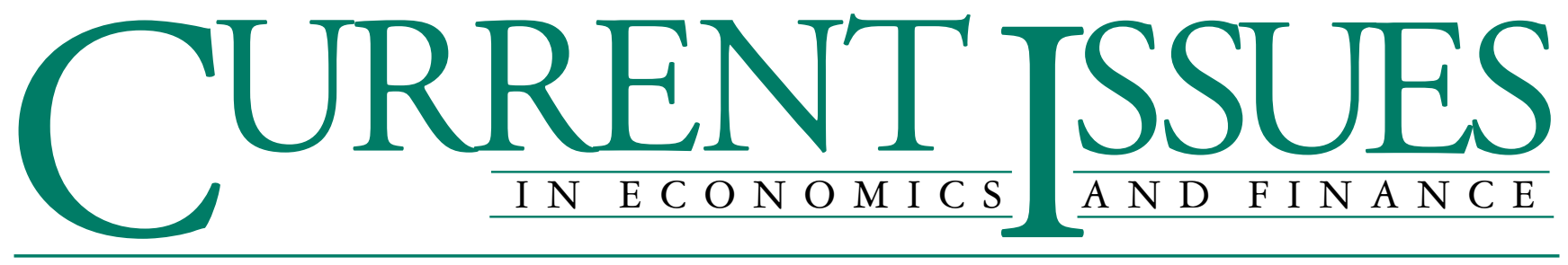

August 2001

Volume 7 Number 8

\title{
To What Extent Does Productivity Drive the Dollar?
}

\author{
Cédric Tille, Nicolas Stoffels, and Olga Gorbachev
}

\begin{abstract}
The continuing strength of the dollar has fueled interest in the relationship between productivity and exchange rates. An analysis of the link between the dollar's movements and productivity developments in the United States, Japan, and the euro area suggests that productivity can account for much of the change in the external value of the dollar over the past three decades.
\end{abstract}

As U.S. labor productivity surged in the second half of the 1990s, the dollar was charting its own upward course against the currencies of the United States' chief trading partners. Between 1995 and 1999, the dollar appreciated 4.8 percent against the yen and 5.8 percent against the euro on an average annual basis. ${ }^{1}$ For some observers, the productivity boom and the dollar's rise were twin manifestations of U.S. economic strength. ${ }^{2}$ Indeed, the parallel timing of these trends suggested that productivity gains were driving the appreciation of the dollar.

In this edition of Current Issues, we use new data from the Organisation for Economic Co-operation and Development (OECD) to analyze more precisely how productivity gains have affected the value of the dollar. After clarifying the theoretical link between the two, we create measures of productivity based on a simple standard framework for the United States, Japan, and the euro area. We then show that these measures do a reasonably good job of explaining the dollar's long cycles over the last three decades. Most notably, we are able to establish that productivity developments accounted for nearly two-thirds of the dollar's appreciation against the euro and three-quarters of its appreciation against the yen in the 1990s.

\section{How Productivity Growth and Currency Value Are Linked}

The Real Exchange Rate

We begin our investigation of the relationship between productivity gains and the strong dollar with a brief look at how we measure the value of a currency. The best gauge of this value is a currency's real exchange rate against a foreign currency. The real exchange rate-defined as the nominal exchange rate adjusted for the ratio of foreign prices to domestic prices ${ }^{3}$ - allows us to compare the purchasing power of different currencies. For example, the real dollar-euro exchange rate compares the quantity of goods that one dollar buys in the United States with the quantity of goods that the same dollar, converted into euros, buys in Europe. Alternatively, one could say that the real exchange rate allows us to compare the cost of a fixed basket of goods in the United States and Europe. Thus, a real appreciation of the dollar-in other words, an increase in the dollar-euro real exchange rate-means that the basket of goods will be more expensive in the United States than in Europe.

\section{The Theory behind the Link}

The impact of productivity gains on a currency's value depends on the distribution of the gains across the "traded" and "nontraded" sectors of the economy. The traded sector is composed of those industries, such as manufacturing, that produce goods for export or goods that compete with foreign imports. The nontraded sector consists of industries - chiefly services - that produce solely for domestic markets from which foreign producers are absent. Price behavior differs markedly in the two sectors. In the traded sector, the price of goods 
is constrained by international competition: companies tend to keep their prices (in common-currency terms) fairly closely aligned with those of producers abroad so as not to lose customers to foreign rivals. By contrast, in the nontraded sector, where industries are not subject to competition, ${ }^{4}$ goods prices tend to vary widely and independently across countries.
Theoretical work by Harrod (1933), Balassa (1964), and Samuelson (1964) has shown that productivity growth will lead to a real exchange rate appreciation only if it is concentrated in the traded sector of an economy. Productivity growth that has been equally strong in the traded and nontraded sectors will have no effect on the real exchange rate.

\section{Box 1: A Simple Theoretical Framework}

To understand how productivity may help determine real exchange rates, consider a two-country world (the United States and "Europe," for example) where a single input, labor, is used to produce both traded and nontraded goods. Because our analysis focuses on the changes in productivity and in the real exchange rate, we express all variables in terms of growth rates. In addition, we express prices and wages for both countries in a common currency (be it the dollar, the euro, or some other currency).

The Harrod-Balassa-Samuelson view of real exchange rate determination is based on four basic principles:

1) The prices of traded goods produced in different countries tend to move together. As traded goods are exchanged on a world market, the price of a good produced in the United States aligns itself with the price of the same good produced in Europe. Formally:

$$
P_{T}^{U S}=P_{T}^{\text {Europe }},
$$

where $P_{T}^{i}$ is the growth rate of the price of traded goods produced in country $i$.

2) The price of nontraded goods can differ across countries, because the goods are not traded on the same market:

$$
P_{N T}^{U S} \neq P_{N T}^{\text {Europe }}
$$

where $P_{N T}^{i}$ is the growth rate of the price of nontraded goods produced in country $i$.

3) Competition for labor among firms leads workers to be paid the (marginal) value of what they produce. When workers become more productive, firms can afford to pay higher wages. Similarly, an increase in wages that is not accompanied by productivity gains leads firms to pass the cost through to consumers in the form of higher prices:

$$
\begin{aligned}
& P_{T}^{U S}=W_{T}^{U S}-O P W_{T}^{U S} \\
& P_{T}^{\text {Europe }}=W_{T}^{\text {Europe }}-O P W_{T}^{\text {Europe }}
\end{aligned}
$$

and

$$
\begin{aligned}
& P_{N T}^{U S}=W_{N T}^{U S}-O P W_{N T}^{U S} \\
& P_{N T}^{\text {Europe }}=W_{N T}^{\text {Europe }}-O P W_{N T}^{\text {Europe }},
\end{aligned}
$$

where $W_{k}^{i}$ is the growth rate of the wage paid to workers in sector $k$ in country $i$, and $O P W_{k}^{i}$ is the growth rate of output per worker (that is, labor productivity).

4) Labor mobility within a country encourages consistency in wages across sectors. For instance, rising wages in the traded sector will boost wages in the nontraded sector because firms want to prevent their employees from leaving their jobs to work in the traded sector:

$$
W_{T}^{U S}=W_{N T}^{U S} \quad \text { and } \quad W_{T}^{\text {Europe }}=W_{N T}^{\text {Europe }} .
$$

From these four principles, ${ }^{\mathrm{a}}$ we derive the exchange rate implications of a productivity boom. Recall that the real exchange rate is the ratio of the aggregate price indexes, with both indexes expressed in the same unit:

$$
\begin{aligned}
R E R= & P^{U S}-P^{\text {Europe }}=\left[\left(1-\alpha^{U S}\right) P_{T}^{U S}+\alpha^{U S} P_{N T}^{U S}\right] \\
& -\left[\left(1-\alpha^{\text {Europe }}\right) P_{T}^{\text {Europe }}+\alpha^{\text {Europe }} P_{N T}^{\text {Europe }}\right],
\end{aligned}
$$

where $R E R$ is the percentage change in the real exchange rate, with an increase corresponding to a real appreciation; $P^{i}$ is the growth rate of the aggregate price index in country $i$; and $\alpha^{i}$ is the weight of nontraded goods in country $i$ 's price index. Combining principles 1-4 with the above definition of the real exchange rate, we construct the Harrod-Balassa-Samuelson (HBS) measure as the percentage change in the real exchange rate caused by the productivity gaps $G A P^{U S}$ and $G A P^{\text {Europe: }}$

$$
H B S=\alpha^{U S} G A P^{U S}-\alpha^{\text {Europe }} G A P^{\text {Europe }} \text {, }
$$

where $G A P^{i}=O P W_{T}^{i}-O P W_{N T}^{i}$ is the sectoral productivity growth gap in country $i$.

${ }^{a}$ Canzoneri, Cumby, and Diba (1999) and Chinn (1997) perform formal tests of these principles for OECD countries. Their results provide broad support for the principles over long horizons.

${ }^{\mathrm{b}}$ This relationship does not rely on the assumption that labor is the only factor of production; an identical relation between the real exchange rate and output per worker is obtained in a model with capital. 
The reasoning behind the theory (presented in more detail in Box 1) is most easily grasped through an example. Suppose that the United States experiences faster productivity growth in the traded sector than in the nontraded sector, creating what we will call a positive sectoral productivity gap. The price of traded goods in the United States will not change, because-as we have seen-it is tied to that prevailing in world markets. The productivity gains in the traded sector will, however, lead to higher wages for workers in these industries. Wages will also rise in the nontraded sector, as employers there seek to retain their workers by offering salaries competitive with those in the traded sector. However, because the productivity gains, if any, in the nontraded sector are smaller than those in the traded sector, firms producing nontraded goods will be unable to absorb the wage increase fully and will be compelled to raise prices. With prices constant in the traded sector and rising in the nontraded sector, the overall U.S. price level will increase. ${ }^{5}$ Consequently, if the foreign price level is unchanged, the rise in domestic prices will translate into an appreciation of the dollar in real terms. Using similar reasoning, we conclude that a negative sectoral productivity gap - that is, slower productivity growth in the traded sector than in the nontraded sector-leads to a real depreciation of the dollar.

Bear in mind, however, that the response to a productivity shock that we have outlined here can be expected to operate only over relatively long horizons, such as decades. It is very unlikely to work over short periodsfor example, from one year to the next-because of slow price and wage adjustments, imperfect competition, trade barriers, and other frictions in the economy. Nevertheless, this framework for understanding the consequences of a productivity shock, though simple, is a standard approach in the analysis of real exchange rate fluctuations, and earlier economic studies have shown that it is indeed relevant over long horizons. ${ }^{6}$

Our framework points to a measure of productivity growth that can be used to assess the relationship between productivity gains and exchange rate movements. The measure-here termed the Harrod-Balassa-Samuelson (HBS) measure - is essentially the difference between the productivity gap (traded-minus-nontraded productivity growth) in the United States and the corresponding gap abroad (see Box 1 for details). By tracking the changes in the HBS measure over time, we can identify the changes in the real exchange rate that can be directly attributed to productivity gains. Thus, an increase of 10 percent in the HBS measure indicates that the real exchange rate would appreciate by 10 percent, assuming that productivity growth is the only driving factor. In the next section, we compute such a measure for the United States, Japan, and the euro area.

\section{Has Productivity Been an Important Determinant of the Dollar Exchange Rate?}

To address this question, we use labor productivity data from the OECD covering the 1970-99 period (see Box 2 for a detailed description of the data). Following common practice in the literature, we break down the data by sector as follows: The traded goods sector includes agriculture, hunting, forestry, and fishing; mining and quarrying; and manufacturing. The nontraded sector includes all other principal industry divisions-electricity, gas, and water; construction; wholesale and retail trade; restaurants and hotels; transport, storage, and communication; finance, insurance, real estate, and business services; and other services and government. In computing the changes in productivity in each sector, we disregard short-lived fluctuations and focus on decade-long horizons over which the link between productivity and the real exchange rates can be expected to hold.

\section{Sectoral Productivity Patterns}

An examination of the sectoral productivity patterns in the United States, Japan, and the euro area over the thirty-year period reveals some interesting features (Chart 1). First, since the productivity changes in the traded and nontraded sectors tend to move in tandem,

\section{Box 2: Data Sources}

We use annual sectoral productivity data from two compatible OECD databases: ISDB (International Sectoral DataBase) and STAN (STructural ANalysis database). Because of the comparability of the two archives, we are able to combine them to obtain consistent series from 1970 to 1999 for the United States, Japan, and four euro area countries: Germany, Italy, France, and the Netherlands. ${ }^{a}$ We compute productivity as the ratio between value added (the value of output minus the cost of intermediary goods, in 1990 dollars) and employment.

The real exchange rates are calculated using the Bank for International Settlements' exchange rate series and the OECD's GDP deflator indexes. ${ }^{b}$ The dollar-euro exchange rate is based on the four countries that we use to represent Europe. This exchange rate tracks very closely an exchange rate based on the twelve euro area countries.

${ }^{a}$ Germany, Italy, France, and the Netherlands account for nearly 80 percent of euro area GDP.

${ }^{b}$ Real exchange rate measures change very little if we use consumer price indexes instead of GDP deflators. 
Chart 1

\section{Annualized Growth Rate of Labor Productivity}
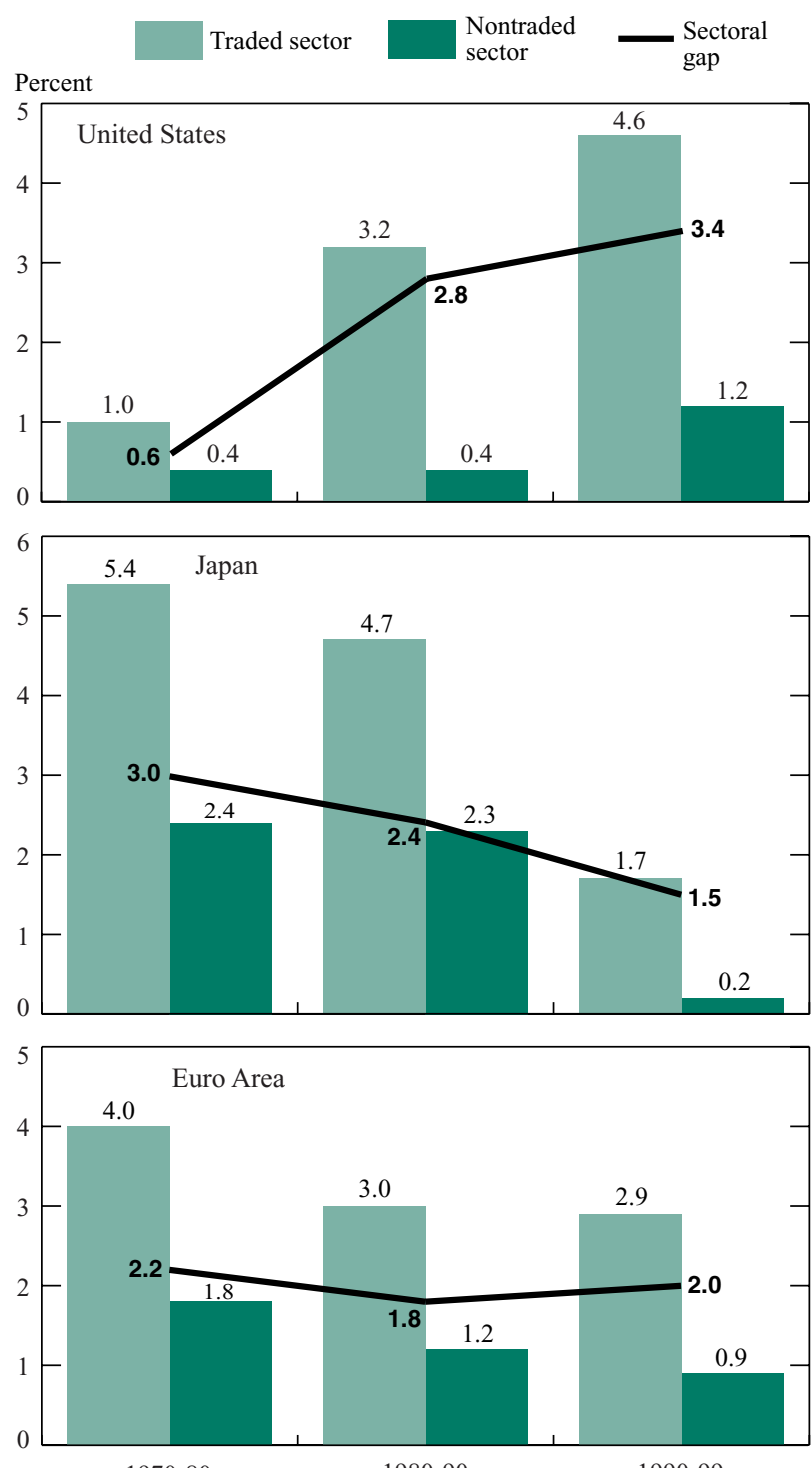

$1970-80$

$1980-90$

1990-99

Sources: Organisation for Economic Co-operation and Development; authors' calculations.

the sectoral productivity gap is much less volatile than the productivity growth rate for the traded sector.

Second, over the last thirty years, the sectoral productivity gap has increased substantially in the United States, while it has remained rather steady in the euro area and has fallen in Japan. In the United States (Chart 1, top panel), this performance mostly reflects the acceleration of productivity in the traded sector. However, it would be misleading to focus solely on this sector. In the 1990s, annual productivity growth in the traded sector exceeded its rate in the 1980 s by 1.4 percentage points. Nevertheless, the increase in the sectoral gap from the
1980 s to the 1990 s was limited to 0.6 percentage point, because productivity growth also picked up in the nontraded sector. ${ }^{7}$

By contrast, Japan (Chart 1, middle panel) has experienced a steady decline in the sectoral productivity gap from the 1970s to the 1990s. The main driving force has been the slowdown of traded sector productivity from its postwar highs: in the 1990s, productivity growth in this sector was 3.7 percentage points lower than in the 1970s. Still, because the nontraded sector has also experienced a productivity slowdown, the sectoral gap has not fallen one-for-one with the decline in traded sector productivity. In the 1990 s, the sectoral gap was 1.5 percentage points below its value for the $1970 \mathrm{~s}$.

Europe's sectoral productivity gap has remained steady over the last three decades, hovering around 2 percent (Chart 1, bottom panel). This performance reflects a uniform productivity slowdown in the traded and nontraded sectors. For instance, in the 1980s, annual productivity growth in the traded sector slowed by 1 percentage point relative to the 1970s. However, because the nontraded sector also experienced a significant productivity slowdown, the gap decreased by only 0.4 percentage point.

\section{Productivity Growth Differentials and the Real Exchange Rate}

Our next step is to combine the sectoral gaps of different areas to construct the HBS measure of productivity growth differentials. ${ }^{8}$ This measure is the appropriate one to determine the extent to which productivity developments can explain real exchange rate fluctuations. As noted earlier, we expect the link between the HBS measure and the real exchange rate to hold only at relatively long horizons. Thus, our analysis focuses on the changes over each decade.

Before assessing the link between productivity and the exchange rate, however, we adjust the exchange rate for very long-run movements that stem from factors unrelated to productivity. Previous studies (Faruquee 1995; Lane and Milesi-Ferretti 2000, 2001) have shown that the real exchange rate is influenced over long horizons by a country's net foreign asset position, which in turn often reflects demographic trends. A country that accumulates foreign assets-for example, to pay for the retirement of its aging population-experiences a regular real appreciation of its currency. Geographical factors can also drive the trend of the real exchange rate. Economic growth bids up the price of scarce resources, leading to higher goods prices. A country where a fixed resource, such as land, is relatively scarce will then experience an increase in the price of its nontraded goods larger than that seen in other countries - in other words, a real appreciation of its currency. 
Chart 2

\section{The Real Exchange Rate and the HBS Measure}

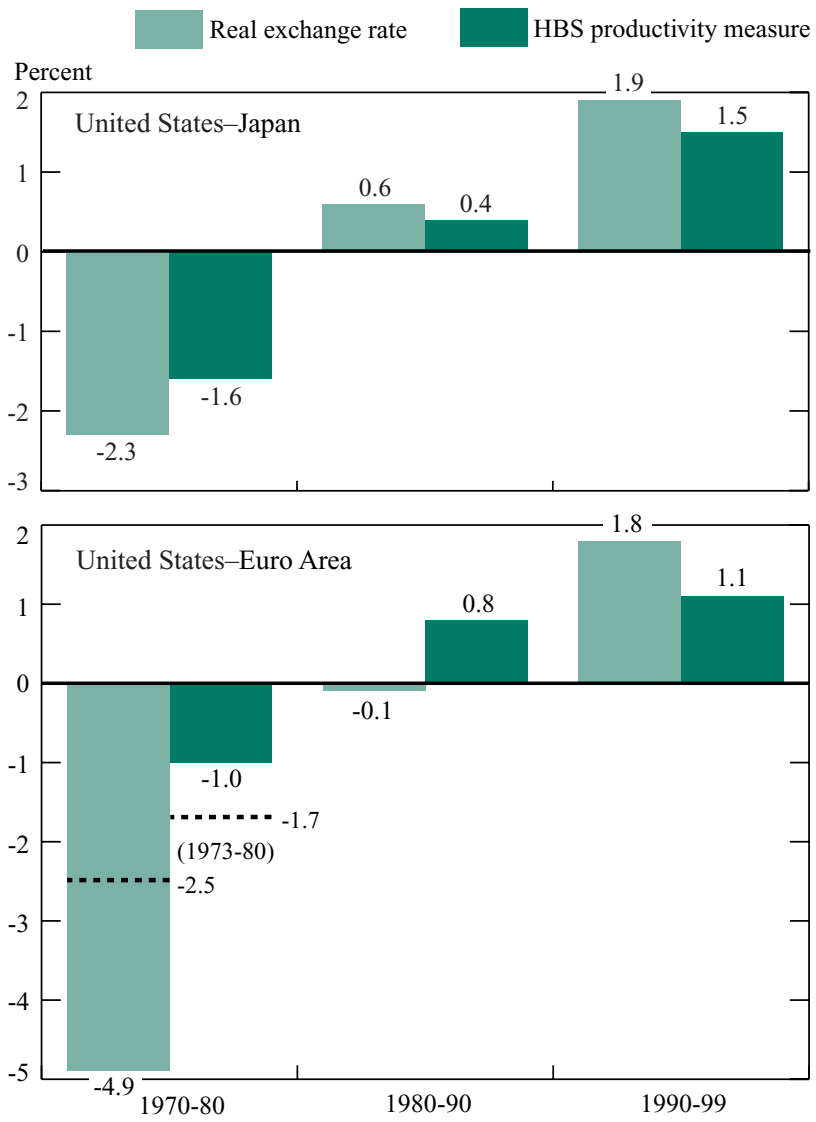

Sources: Organisation for Economic Co-operation and Development; Bank for International Settlements; authors' calculations.

Notes: The dollar-yen real exchange rate is detrended. Positive values correspond to a dollar appreciation. Growth rates are annualized.

We capture such long-run factors by examining the presence of any trend in the exchange rate over the three decades in our sample. Although we find no evidence of such a trend for the dollar-euro exchange rate, the dollaryen exchange rate does exhibit a tendency for the yen to appreciate. ${ }^{9}$ This finding reflects the sizable and steady accumulation of foreign assets by Japan over the period and the accompanying increase in U.S. foreign liabilities, related developments that can be linked to demographic factors such as the more pronounced aging of the population in Japan. ${ }^{10}$ Furthermore, the relative scarcity of land in Japan could also lead to a trend appreciation of the yen. We control for these long-run factors by removing the trend appreciation of the yen from the dollar-yen exchange rate. ${ }^{11}$

Our analysis shows that the HBS measure accounts for a large fraction of the "detrended" exchange rate movements between the dollar and the yen (Chart 2, top panel). In the $1970 \mathrm{~s}$, the dollar depreciated by 2.3 per- cent annually, before appreciating moderately in the 1980 s (0.6 percent) and strongly in the 1990 s (1.9 percent). These movements are well explained by the HBS measure, which accounts for more than two-thirds of the exchange rate fluctuations.

The HBS measure also performs well, though not perfectly, in accounting for the swings of the dollareuro exchange rate (Chart 2, bottom panel). A fifth of the 4.9 percent annual depreciation of the dollar in the 1970 s can be attributed to the sectoral gap in Europe. The fit is much closer over the years following the breakdown of the Bretton-Woods System of fixed exchange rates. The HBS measure accounts for twothirds of the 2.5 percent annual depreciation of the dollar between 1973 and 1980. The link between the HBS measure and the exchange rate is relatively weak in the 1980s, when the dollar depreciated slightly against the euro although the HBS measure pointed to an appreciation. The HBS measure does a much better job of accounting for the exchange rate in the 1990s, with nearly two-thirds of the 1.8 percent annual appreciation of the dollar being attributable to productivity growth differentials.

Our finding that productivity gaps play a significant role in driving the real exchange rate over the long run is consistent with the results of other recent studies. ${ }^{12}$ The fraction of exchange rate fluctuations that cannot be explained by productivity could reflect several additional factors. Although developing a more complete framework encompassing them is beyond the scope of this contribution, the literature points to a role for government spending ${ }^{13}$ and the terms of trade. ${ }^{14}$

\section{Conclusion}

Using a simple framework, we find that differences in productivity growth in the United States and its main trading partners account to a substantial extent for the ten-year swings of the real dollar exchange rate over the past thirty years. In particular, the robust productivity gains experienced by the United States in the 1990s go a long way toward explaining the strengthening of the dollar against the yen and the euro.

\section{Notes}

1. For the period before 1999, we use a "synthetic" euro constructed as a weighted basket of the currencies of the euro area countries.

2. See the Economist (2001).

3. Formally, $R E R=E R \times P^{U S} / P^{F}$, where $R E R$ and $E R$ are the real and nominal exchange rates, respectively (in units of foreign currency per dollar, so an increase corresponds to an appreciation of the dollar), and $P^{U S}$ and $P^{F}$ are the U.S. and foreign price levels, respectively. 
4. Prohibitive transportation costs prevent consumers from taking advantage of international differences in the price of nontraded goods (examples are health care and haircuts).

5. The finding that productivity gains in the United States lead to higher prices may appear puzzling. Note, however, that because the productivity increase boosts wages by more than prices, the purchasing power of U.S. workers (wages deflated by the price index) increases.

6. See Begum (2000), Canzoneri, Cumby, and Diba (1999), and Chinn (1997).

7. The point is even sharper if we contrast the two halves of the 1990s. Between 1995 and 1999, productivity grew annually by 5.6 percent in the traded sector, 1.8 percentage points faster than between 1990 and 1995 . However, the gap increased by only 0.4 percentage point, from 3.2 percent in the first half of the 1990 s to 3.6 percent in the second half.

8. The computation is detailed in Box 1. The weight of nontraded goods (represented by $\alpha$ ) in the measure is the average valueadded share of the nontraded sector between 1970 and 1999. This equaled 0.76 for the United States, 0.70 for the euro area, and 0.71 for Japan. These shares were quite steady throughout the sample and are consistent with the value of 0.75 considered by Obstfeld and Rogoff (2001).

9. The trend corresponds to a 2.8 percent annual appreciation of the yen against the dollar.

10. Between 1970 and 1997, Japan accumulated U.S.\$1.3 trillion in foreign assets, whereas the United States accumulated U.S.\$2 trillion in foreign liabilities (Lane and Milesi-Ferretti 2001).

11. Despite its simplicity, our method leads to results that are in line with more complete estimations based on the changes in foreign asset holdings (Faruquee 1995).

12. See, for instance, Begum (2000), De Gregorio and Wolf (1994), and Faruquee (1995).

13. Because an increase in government spending is concentrated in nontraded goods, it will tend to boost their price and thereby appreciate the currency (Chinn 1997).

14. Favorable terms of trade make a country wealthier, boosting consumption of all goods, including nontraded goods. This outcome raises the price of nontraded goods and causes the real exchange rate to appreciate.

\section{References}

Balassa, Bela. 1964. "The Purchasing Power Parity Doctrine: A Reappraisal.” Journal of Political Economy 72: 584-96.

Begum, Jahanara. 2000. "Real Exchange Rates and Productivity: Closed Form Solutions and Some Empirical Evidence." International Monetary Fund Working Paper no. 00/99.

Canzoneri, Matthew, Robert Cumby, and Behzad Diba. 1999. "Relative Labor Productivity and the Real Exchange Rate in the Long Run: Evidence for a Panel of OECD Countries." Journal of International Economics 47, no. 2 (April): 245-66.

Chinn, Menzie. 1997. "Sectoral Productivity, Government Spending and Real Exchange Rates: Empirical Evidence for OECD Countries.” NBER Working Paper no. 6017.

De Gregorio, Jose, and Holger Wolf. 1994. "Terms of Trade, Productivity and the Real Exchange Rate.” NBER Working Paper no. 4807.

Economist. 2001. "The Darling Dollar." Special issue, vol. 359, no. 8216 (April 7): 81-2.

Faruquee, Hamid. 1995. "Long-Run Determinants of the Real Exchange Rate: A Stock-Flow Perspective." International Monetary Fund Staff Papers 42: 80-107.

Harrod, Roy. 1933. International Economics. London: James Nisbet and Cambridge University Press.

Lane, Philip, and Gian Maria Milesi-Ferretti. 2000. "The Transfer Problem Revisited: Net Foreign Assets and Real Exchange Rates.” International Monetary Fund Working Paper no. 00/123.

. 2001. "Long-Term Capital Movements.” NBER Working Paper no. 8366, June.

Obstfeld, Maurice, and Kenneth Rogoff. 2001. "Perspectives on OECD Economic Integration: Implications for U.S. Current Account Adjustment." In Global Economic Integration: Opportunities and Challenges, 169-208. Proceedings of a Federal Reserve Bank of Kansas City conference.

Samuelson, Paul. 1964. "Theoretical Notes on Trade Problems." Review of Economics and Statistics 46: 145-54.

\section{About the Authors}

Cédric Tille is an economist in the International Research Function of the Research and Market Analysis Group; Nicolas Stoffels, a senior economist at the Swiss National Bank, is a visiting senior economist in the function. Olga Gorbachev, formerly an assistant economist in the function, is now a graduate student in economics at Columbia University.

The views expressed in this article are those of the authors and do not necessarily reflect the position of the Federal Reserve Bank of New York, the Federal Reserve System, or the Swiss National Bank.

Current Issues in Economics and Finance is published by the Research and Market Analysis Group of the Federal Reserve Bank of New York. Dorothy Meadow Sobol is the editor. 